- THE PATH TO A MODERN SOUTH 
This page intentionally left blank 


\section{THE PATH TO A MODERN SOUTH}

Northeast Texas between Reconstruction and the Great Depression

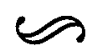

WALTER L. BUENGER

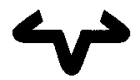

UNIVERSITY OF TEXAS PRESS AUSTIN 
Copyright $(\mathcal{C} 200$ I by the University of Texas Press

All rights reserved

Printed in the United States of America

First edition, 200I

Requests for permission to reproduce material from this work should be sent to Permissions, University of Texas Press, Box 7819, Austin, Tx

$$
\text { 78713-7819. }
$$

(0) The paper used in this book meets the minimum requirements of ANSI/NISO Z39.48-I992 (RI997) (Permanence of Paper).

Library of Congress Cataloging-in-Publication Data

Buenger, Walter L. (Walter Louis), I95I-

The path to a modern South : northeast Texas between reconstruction and the great depression / Walter L. Buenger. - Ist ed.

p. $\quad \mathrm{cm}$.

Includes bibliographical references (p. ) and index.

ISBN 0-292-70887-4 (cloth : alk. paper) -

ISBN 0-292-70888-2 (pbk. : alk. paper)

I. Texas-History $-1846-1950$. 2. Texas-Social conditions. 3. TexasEconomic conditions. 4. New Deal, 1933-1939-Texas. 5. World War, 1939-1945-Texas. 6. World War, I939-1945-Influence. 7. Social change-Texas-History. I. Title.

F39I .B 878 200I

$976.4^{\prime} 806 \mathrm{I}-\mathrm{dc} 2 \mathrm{I} \quad 00-0615 \mathrm{I}$ 
For Vickie 
This page intentionally left blank 